P. Shyshchenko, Doctor of Science in Geography, Professor, O. Havrylenko, PhD Geography, Associate Professor

Taras Shevchenko National University of Kyiv, Kyiv, Ukraine

\title{
GEOECOLOGY IN THE SCIENTIFIC AND EDUCATIONAL DIMENSION
}

Geoecological paradigm incipience has formed an interdisciplinary geoecology, which purpose is to optimize the nature using on the basis of geoecosystem interconnections study and integration of the acquired knowledge into the practice of territorial planning and management. An important sphere of geoecological research practical application results is the creation of an optimal structural and functional organization of the territory for substantiation of various nature management projects. With the help of estimating and predictive research methods, the degree of geoecosystems suitability for the projected nature using kinds is established. Forecast geoecological researches are aimed at preventing possible destructive natural processes, identifying anthropogenic influences and caused by the negative changes in the natural environment. On the results of evaluative and forecast geoecological research, the adoption of final design and planning decisions should be based. Based on results of the conducted research the following conclusions have been made:

1. The priority task of applied geoecology is to prevent the emergence of crisis and emergency geoecological situations. Therefore, in the near future, it would be expedient to teach applied geoecology a separate academic discipline.

2. Solving the constructive tasks of geoecological research requires the corresponding specialty and education of researchers.

3. Basic geoecological knowledge is laid out by the educational system with the use of innovative active methods in the educational process, in particular, the project method. For this purpose, the discipline "Geoecology of Ukraine" is taught at the Faculty of Geography of the Kyiv Taras Shevchenko National University for masters of the first year of study.

4. The lecturer stimulates the project activity, directing the work of students to achieve the final result - the geoecological project presentation. For example, the implementation of the project on discipline "Geoecology of Ukraine" involves students fulfilling such basic tasks - search, analysis and systematization of information; choice of research methods; drawing up of maps, diagrams, charts; formulating the conclusions of the study and developing the presentation of the project.

5. The topic of the project is most often associated with specific practical issues relevant to real life. The study of the discipline "Geoecology of Ukraine" promotes orientation of students for the specialty of the environmental manager, designer, expert on environmental projects, etc.

Keywords: geoecosystems, geoecological estimation and forecasting, substantiation of nature management projects, project method, geoecological education.

О. Бейдик, д-р геогр. наук, профр. Київський національний університет імені Тараса Шевченка, Київ, О. Топалова, канд. геогр. наук Мелітопольський державний педагогічний університет імені Богдана Хмельницького, Мелітополь

\section{ТЕОРЕТИКО-ПРАКТИЧНІ АСПЕКТИ РЕКРЕАЦІЙНО-ТУРИСТИЧНОГО ПРИРОДОКОРИСТУВАННЯ}

Розглянуто природокористування як одна з прикладних наукових галузей, що базується на природонаукових знаннях і комплексі фундаментальних суспільно-економічних дисциплін, з одного боку, а з іншого - як розгалужена і потужна практика та суспільний досвід використання природних умов природних ресурсів. Розкрито основні етапи наповнення та структуру програми 3 природокористування, яка складена відповідно до освітньо-професійної програми підготовки фахівців за освітньо-кваліфікаційним рівнем "магістр" з напряму підготовки "Сфера обслуговування" за спеціальністю "Туризмознавство". Наведено низку структурно-логічних моделей з обраної тематики. Проведені дослідження та якісне оцінювання природних компонентів у межах НПП України можуть компенсувати неповний реєстр даних ресурсної бази адаптивного туризму та стати своєрідною "дорожньою картою" при реалізації різноманітних туристсько-адаптивних програм для маломобільної категорії населення.

Ключові слова: природокористування, структурно-логічне моделювання, адаптивний туризм.

Вступ. Постановка проблеми. Природокористування $€$ одним з наріжних каменів успішного функціонування економіки будь-якої країни, а економічний та суспільно-географічний аналіз (оцінювання) природних ресурсів - одним із пріоритетів їх ефективного використання. Дисципліни з природокористування та рекреаційно-туристичного природокористування у ВНЗ України (географічні, геолого-географічні, природно-географічні фракультети національних, педагогічних університетів) $є$ базовими впродовж багатьох років. Наприклад, на географрічному фракультеті КНУ (кафедра країнознавства та туризму) викладається нормативна навчальна дисципліна "Теорія та практика рекреаційнотуристичного природокористування", яка складена відповідно до освітньо-професійної програми підготовки фахівців за освітньо-кваліфікаційним рівнем "магістр" 3 напряму підготовки "Сфера обслуговування" за спеціальністю "Туризмознавство".

Аналіз останніх досліджень і публікацій. Теоретико-практичним питанням природокористування присвячені роботи М. Ф. Реймерса, С.П. Хромова, О.И. Чеботарьова, Г.С.Горшкова, О. Є. Криволуцького, комплексному економічному оцінюванню природних ресурсів як одному з головних факторів розвитку та розміщення виробничих сил - публікації й монографії
О. О. Мінца, А. Г. Аганбегяна, Е. Б. Алаєва, оцінці природно-ресурсного потенціалу - монографії В. П. Руденка, М.Г. Ігнатенка, аналізу природних рекреаційнотуристичних ресурсів - піонерні роботи Л.І. Мухіної, В. С. Преображенського, Ю. О. Веденіна, Б. М. Ліханова, І. В. Зоріна, О. О. Бейдика. За М.Ф. Реймерсом (1990) [7] природокористування двоєдине: 1) це одна 3 прикладних наукових галузей, що базується на природонаукових знаннях і комплексі фундаментальних суспільно-економічних дисциплін; 2) це розгалужена і потужна практика та суспільний досвід використання природних умов природних ресурсів. О. О. Мінц [5] розглядає питання економічної оцінки природних ресурсів теоретично як загальнішу проблему взаємодії природи і суспільства, а також практично - як стратегію розвитку національної економіки.

Викладення основного матеріалу. Наповнення та структура програми з природокористування. Об'єктом вивчення дисципліни є природні рекреаційнотуристичні ресурси або природні умови, які оцінені економічно або іншим чином і залучені до рекреаційнотуристичної сфери. Предметом вивчення навчальної дисципліни $є$ просторова організація, оцінювання, класифікація та інші аспекти рекреаційно-туристичного природокористування. Мета і завдання дисципліни ви- 
пливають як з її предмет-об'єктної сутності, так і з концепцій національної вищої освіти. Мета дисципліни розкрити конструктивну специфіку рекреаційно-туристичного природокористування. Завдання - поглиблення та розширення уявлень про природокористування та рекреаційне природокористування як базову наукову категорію, її сутність і структуру; ознайомлення з теоретико-методологічними основами рекреаційно-туристичного природокористування та методологічною системою його дослідження; аналіз рекреаційно-туристичного природокористування в системі національних парків.

У результаті вивчення навчальної дисципліни студент повинен знати: терміни і поняття, теоретичні положення й методи дослідження, специфічні вияви рекреаційно-туристичного природокористування; вміти: застосовувати в процесі дослідження теоретичні положення та методи оцінювання стану рекреаційнотуристичного природокористування, а також поняттєвотермінологічний апарат; картографувати різноманітні вияви рекреаційно-туристичного природокористування.

зв'язок з іншими дисциплінами. Дисципліна має тісний зв'язок із дисциплінами, які викладались студентам упродовж першого - четвертого курсів (ОР "бакалавр"): "Рекреаційно-туристичні ресурси", "Географрія рекреації та туризму", "Рекреаційні комплекси", "Менеджмент туризму", "Методика розробки турів", "Економічна оцінка природних ресурсів". Програма навчальної дисципліни складається з таких змістових модулів: 1. Теоретичні положення рекреаційно-туристичного природокористування. 2. Практика рекреаційнотуристичного природокористування. 3. Аналіз рекреаційно-туристичного природокористування на території України. До першого модуля входять такі теми: природокористування як базова наукова категорія; рекреаційне природокористування, його сутність та структура; теоретико-методологічні основи рекреаційно-туристичного природокористування; методологічна система дослідження рекреаційно-туристичного природокористування. Другий модуль складається з тем: специфіка рекреаційно-туристичного природокористування; курорт як система рекреаційно-туристичного природокористування; рекреаційно-туристичне природокористування в системі національних парків; географрічні аспекти концепції рекреаційного природокористування. Третій модуль включає такі теми: ресурсно-рекреаційне районування України; класифікація та оцінка природних ресурсів; праці О.Є. Криволуцького, О. О. Мінца, В. С. Преображенського, В. П. Руденка, М. Г. Ігнатенка; сутність і становлення SWOT-аналізу; аналіз рекреаційно-туристичного природокористування на території Причорноморського ресурсно-рекреаційного району; аналіз рекреаційно-туристичного природокористування на території Карпатського ресурсно-рекреаційного району; аналіз рекреаційно-туристичного природокористування на території Подільського ресурсно-рекреаційного району; аналіз рекреаційно-туристичного природокористування на території Харківського ресурснорекреаційного району; аналіз рекреаційно-туристичного природокористування на території Полісько-Столичного ресурсно-рекреаційного району; аналіз рекреаційнотуристичного природокористування на території Придніпровсько-Донецького ресурсно-рекреаційного району.

Структурно-логічне (наочно-уявне) моделювання. При викладанні дисциплін природо-ресурсного блоку та реалізації практичних завдань залучаються класичні методи пізнання, одним з яких $є$ метод моделювання. Метод моделювання має широке поле діяльності та значну диверсифрікацію. Одним із найбільш уживаних $€$ картографрічний i метод структурнологічного моделювання. Останній дає можливість як узагальненого, генералізованого (дедуктивного), так і конкретно-вибіркового (індуктивного) підходу при аналізі суспільних явищ і процесів. Реалізація картографічного методу дає узагальнену й водночас конкретновибіркову картину просторового (просторово-часового) положення (стану) процесу або явища. Наприклад, при дослідженні природно-географічних чинників формування адаптивного туризму і створенні картографрічних моделей "Регіональні відмінності оцінки чинників розвитку адаптивного туризму" та "Можливості національних природних парків щодо організації туристичноекскурсійних маршрутів для осіб з інвалідністю" використовувалися відповідні алгоритми та концепції рекреаційно-туристичного природокористування.

Вивчення наукової спадщини провідних ученихприродоресурсників, реалізація методики рекреаційного оцінювання природних умов, опанування теоретикопрактичних аспектів рекреаційно-туристичного природокористування, законів і аксіом природокористування було втілено у відповідні структурно-логічні моделі (рис. 1-3).

Природно-географічні чинники формування адаптивного туризму. Природні ресурси, їх оцінка відіграють важливу роль у розвитку адаптивного туризму. До природно-географрічної групи чинників адаптивного туризму належать ландшафти, орографічні, фрауністичні, кліматичні компоненти природи, спелеоресурси, рослинні, природні унікуми, природні й біосфрерні заповідники, заказники, національні природні парки, дендропарки, ботанічні сади, зоопарки. Важливим в організації заходів адаптивного туризму є урахування кліматичних умов - наявність сонячного сяяння, ультрафріолетової радіації, чистого, насиченого фрітонцидами та іонами повітря. На сучасному етапі розвитку видів адаптивного туризму використання клімату як реабілітаційного чинника дозволяє виявити перспективні туристичні дестинації I та II порядку, які застосовують аеро-, геліо-, таласотерапію тощо. Переважна більшість регіональних реабілітаційних закладів і установ України в комплексі реабілітаційних заходів, окрім традиційних, застосовують ландшафтотерапію й об'єкти, що вирізняються мікрокліматичними особливостями, наприклад печери, шахти (спелеотерапія).

Сприятливими кліматичними умовами для розвитку адаптивного туризму за реабілітаційним спрямуванням вирізняються АР Крим, Івано-Франківська та Закарпатська області. У цих областях під впливом підсилюючої поверхні (форми рельєфу, рослинність, водойми) виникає місцева повітряна циркуляція, що визначає особливості їх мікроклімату. Нерідко саме мікрокліматичні особливості вказують на перспективу появи елементів туристичної інфрраструктури (пункт, маршрут) реабілітаційної спрямованості. Південний берег Криму - один із основних кліматичних туристичних районів України. У межах цього району вже діє значна кількість туристичних об'єктів, що надають послуги особам з обмеженими фізичними та психофрізичними можливостями.

Кліматичні умови Карпат комфортніші для організації зимових видів адаптивного туризму (хендскі, паравокінг), а в передгірних районах Закарпаття - як зимових, так і літніх. Важливими кліматичними курортами Карпатського регіону для надання спеціалізованих туристичних послуг є Ворохта, Косів, Шешори, Яремча, Ясіня, Яблуниця, Славське, Сойми, Перечин, Чинайдиво, Кобилецька Поляна.

Перспективним для розвитку адаптивного туризму $є$ розташування об'єктів кліматолікування поблизу великих міст (Конча-Заспа, Феофанія в зоні впливу м. Києва) і в обласних центрах (курортна місцевість Соснівка, м. Черкаси) або ж використання сприятливих мікрокліматичних властивостей території (Заліщики, Тернопільська обл.), що значно полегшує апроксимування людей із особливими потребами. Кліматичні курорти й курорт- 
ні місцевості зосереджені переважно навколо Києва та в його межах - Ворзель, Пуща-Водиця, Буча, Клавдієве, Тарасове, Лютіж і Святошин. Варто зазначити курорт Горинь (Рівненська обл.) і курортні місцевості Дениші (Житомирська обл.), Грем'яч (Чернігівська обл.).

Україна відносно багата якісними й унікальними джерелами мінеральних вод, родовищами лікувальних грязей і озокериту, які мають територіальне поширення по всіх областях, однак особлива територіальна концентрація і різноманітність складу характерна для мінеральних вод у Карпатському регіоні, на півночі лісостепу та Азово-Чорноморського узбережжя. Якщо не брати до уваги Сиваш, то на Україну припадає 43 \% найпривабливіших у рекреаційному та реабілітаційному сенсі бе- регів Азовського моря. Зважаючи на мілководність (типова глибина 7,4 м, максимальна 15 м), температура поверхневого шару Азовського моря влітку становить від +25 до $+32^{\circ} \mathrm{C}$. Тривалість купального сезону в Азово-Чорноморському басейні становить понад 4 місяці - з кінця травня до початку жовтня. Однак в Україні незначна кількість пляжів доступна для відвідування туристами з обмеженими функціями організму, зокрема спеціалізовані пляжі фрункціонують на курортах Криму (Євпаторія), Одеси, Бердянська, Маріуполя. Загальна місткість усіх пляжів України за відвідуваністю оцінюється в 5 млн чоловік і лише незначна кількість пляжів надає послуги 500 особам з інвалідністю (Бердянськ, Одеса, Саки, Євпаторія).

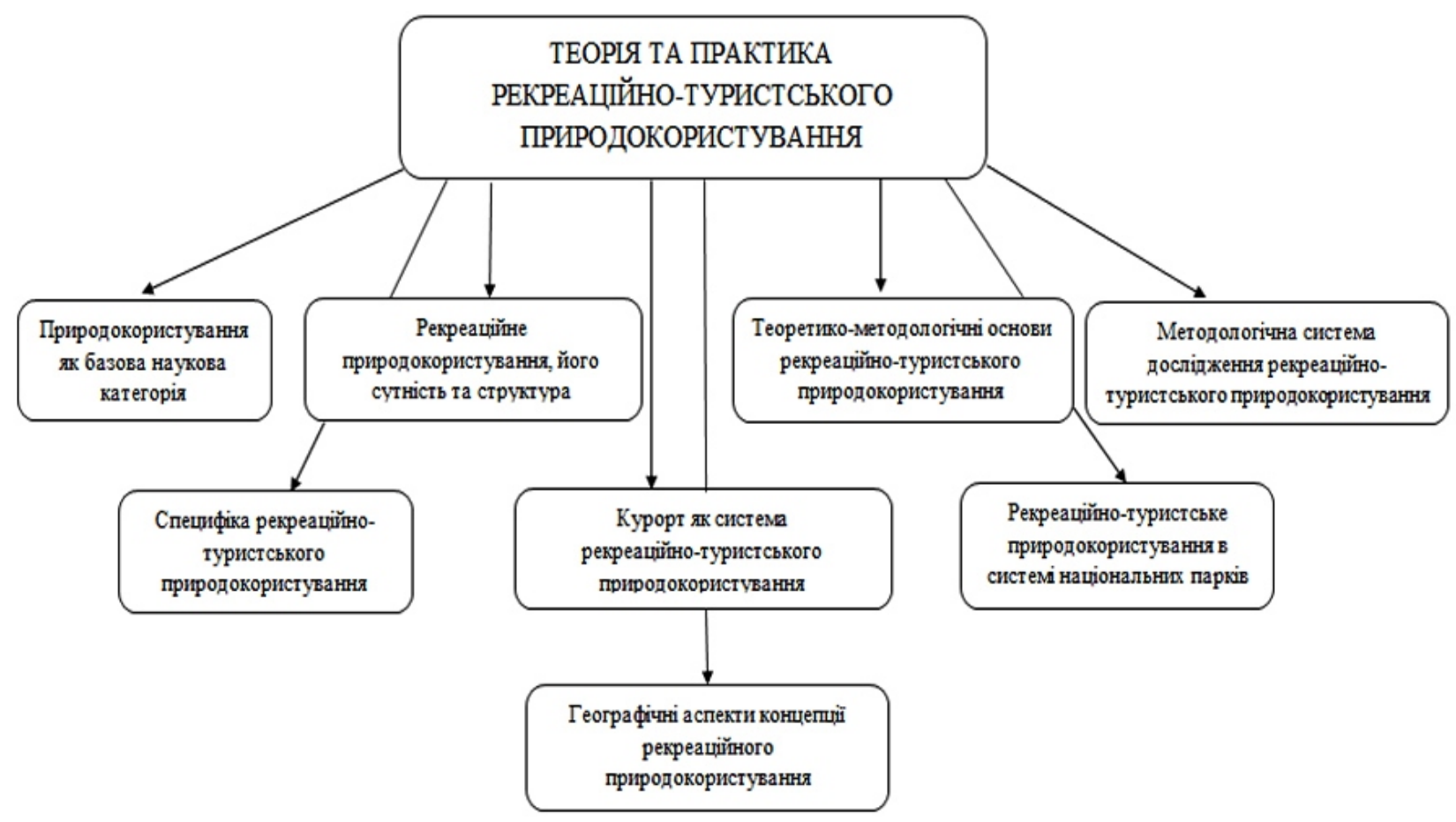

Рис. 1. Структурно-логічна модель "Теорія та практика рекреаційно-туристичного природокористування"

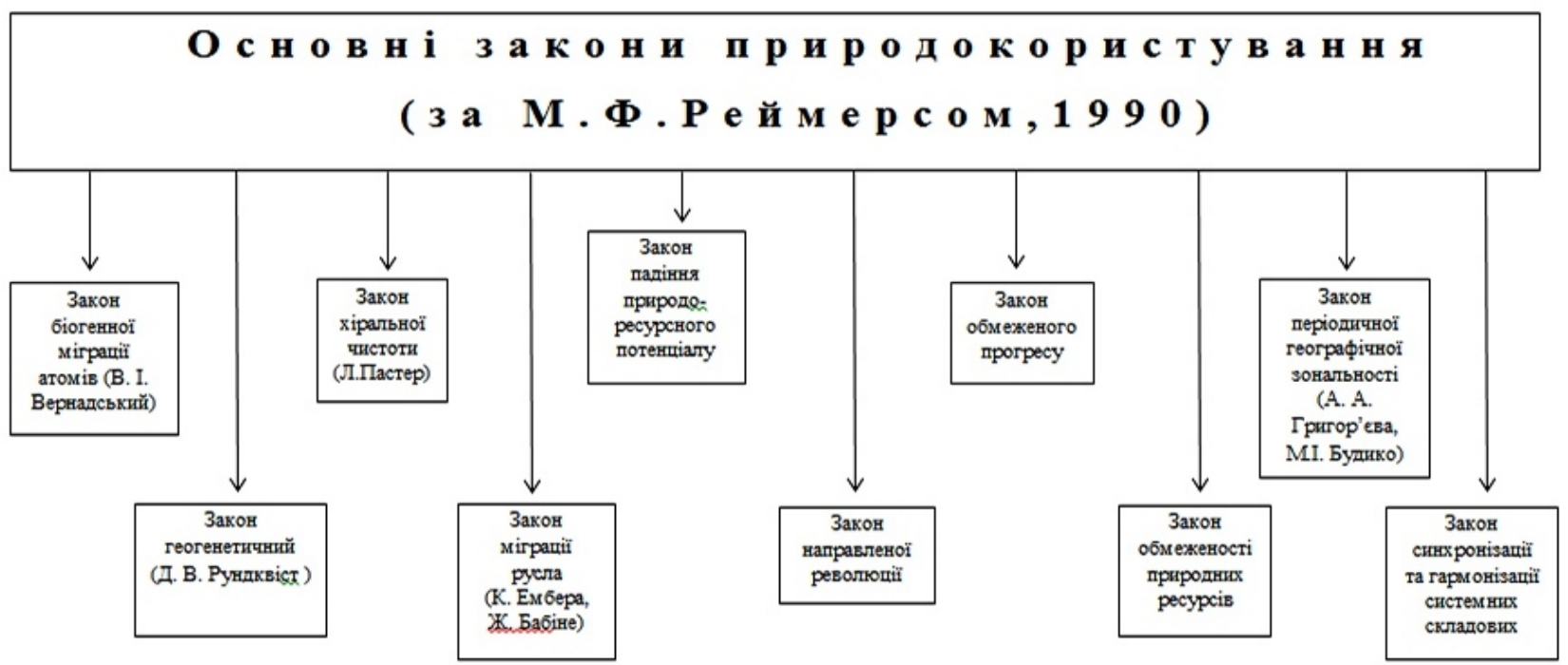

Рис. 2. Основні закони природокористування 


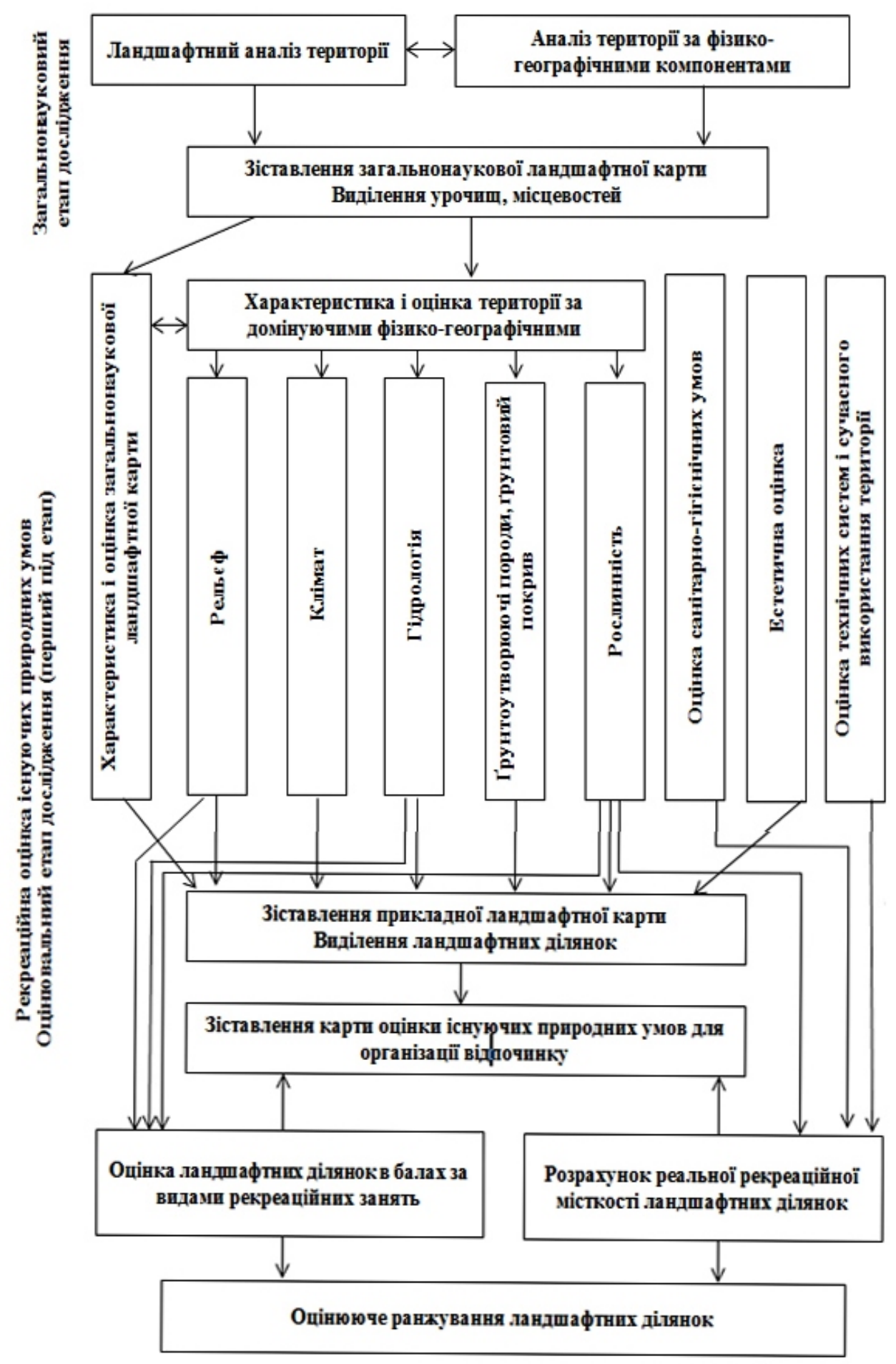

Рис. 3. Принципова схема методики рекреаційного оцінювання природних умов

В Україні, за даними Державної агенції водних ресурсів, налічується близько 20 тис. озер, у т. ч. 43 із площею понад $10 \mathrm{kм}^{2}$. Озера України мають велике значення для організації адаптивного туризму та реабілітації. Вони придатні для купання, рибальства, занять водними видами спорту й оздоровлення, а головне вони доступні для відвідування особами з інвалідністю. Географрічно озера України об'єднуються в такі групи: Шацькі, Турійські (Волинська обл.); Слов'янські (Донецька обл.); Перекопські, Євпаторійські, Керченські (АР Крим); Придунайські (Одеська обл.). Найбільшу бальнеологічну цінність мають приморські озера та лимани, оскільки вони є місцем зосередження лікувальних гря- зей (Сасик, Тигульський, Хаджибейський, Куяльницький, Утлюкський лимани). У заходах реабілітаційного спрямування задіяні озера Люб'язь, Волянське, Оріхове, Турське (Волинська обл.). У перспективі доцільним $€$ обладнання туристичних зон Полісся, розташованих поблизу озер Білого, Нобеля (Рівненська обл.), Борового, Оріховського, Десняка (Чернігівська обл.).

На сучасному етапі розвитку адаптивного туризму в Україні надзвичайно широким спектром туристичних послуг вирізняються річки. Хоча переважна кількість річок не мають безпосередньо реабілітаційного значення, вони є невід'ємною складовою краєвиду й за певних сприятливих умов (чиста вода, невеличкі струмки, ат- 
рактивність ландшафту) приваблюють туристів. Найбільше рекреаційне навантаження припадає на р. Дніпро та її притоки (Тетерів, Рось, Тясмин, Інгулець, Десну, Сулу, Псел, Ворсклу, Самару).

Певне значення для розвитку адаптивного туризму мають туристичні біотичні ресурси, тобто ресурси живої природи, сприятливі як для лікування, оздоровлення, реабілітації, так і для задоволення духовних потреб людини й організації окремих видів туризму (мисливські, фріш-тури).

Варто зазначити, що важливими передумовами розвитку адаптивного туризму та появи спеціалізованих туристичних одиниць (пунктів, маршрутів) реабілітаційної спрямованості $€$ орографрічні особливості території України, більша частина якої, за винятком двох гірських систем (Українські Карпати та Кримські гори), має рівнинний рельєф, де майже відсутні істотні природні перешкоди, що уможливлює проходження груп із обмеженням функцій рухового апарату.

Природно-географфічні ресурси України сприяють розвитку різних видів адаптивного туризму, у т. ч. адаптивного скелелазіння. Адаптивне скелелазіння (параклимбінг) - це найбільш доступний вид адаптивного туризму для різних категорій інвалідності, ним можна займатися як у природних умовах, так і на штучних спорудах (скеледромах). Якщо природні скелелазні місця характерні для гірських районів Криму та Карпат, то штучні споруди (скеледроми, боулдерінгові зали) $€$ в кожній області України. Значна їх кількість розташована в регіонах, де відсутні природні скелелазні місця (Київська, Дніпропетровська, Донецька, Харківська обл.).

Останнім часом, крім традиційних видів реабілітації (медична, фрізична, трудова тощо), у реабілітаційних установах і закладах України почали практикувати нетрадиційні (ландшафто-, спелео-, киснетерапія тощо). Значна кількість нетрадиційних видів реабілітації залежить від природно-географічних особливостей і умов регіону. Наприклад, послугами з ландшафтоперапії вирізняються АР Крим, Закарпатська, Тернопільська області, де значна кількість території представлена хвойними та реліктовими лісами.

Серед нетрадиційних видів реабілітації популярності набуває анімалотерапія (цілеспрямоване використання спеціально навчених тварин або їх символів за допомогою адресно розроблених терапевтичних програм). В анімалотерапії задіяні не тільки самі тварини, але й їхні образи та звуки. Спрямована анімалотерапія, своєю чергою, складається з певних видів, залежно від того, які саме тварини використовуються, і поділяється на іпо-, дельфіно-, каніс-, фелінотерапію. Ці напрями застосовують для лікування та профрілактики різних захворювань.

Іпотерапія - метод лікування, заснований на взаємодії людини зі спеціально навченим конем, адаптованим до можливостей хворого в опануванні верхової їзди. Іпотерапію застосовують при порушеннях опорнорухового апарату, атеросклерозі, черепно-мозкових травмах, поліомієліті, шлунково-кишкових захворюваннях, простатиті, сколіозі, розумовій відсталості. У медичних центрах (а також у психотерапії) використовують дельфінів. Спілкування з дельфрінами допомагає стабілізувати психоемоційний стан людини, зняти психологічну напругу. Людина заспокоюється, починає нестандартно мислити, швидко знаходить вихід із кризової ситуації. Дельфінотерапія - це психологічна реабілітація для людей, що потрапили в екстремальні умови, пережили землетруси, буревії, аварії й будь-який інший сильний психоемоціональний стрес, і дітей із захворюваннями нервової системи: олігофренією, синдромом Дауна. Набуває поширення в адаптивному туризмі й каністерапія - вид анімалотерапії з використанням собак. Тільки за 2013 р. мережею реабілітаційних закла- дів організовано понад 12 тис. виїзних заходів для осіб з інвалідністю із застосуванням методів анімалотерапії в межах регіонів України.

Аналіз надання реабілітаційних послуг установами й закладами України показав, що в значній кількості регіонів крім традиційних (фізична, трудова, психологічна, соціальна, професійна) видів терапії надають послуги за допомогою нетрадиційних (спелео-, іпо-, бальнео-, кінезотерапія тощо) видів. Аналіз змісту й видів реабілітаційних заходів, що надають оздоровчі установи, визначив, що повним спектром видів реабілітаційних послуг вирізняються АР Крим, Донецька, Тернопільська області, Київ і Севастополь, а значна кількість областей України пропонує традиційний пакет реабілітаційних послуг.

На сучасному етапі розвитку ринку туристичних послуг в Україні (незважаючи на політичні проблеми, економічну кризу, природні лиха та ін.) серед маломобільної категорії населення значної популярності набуває активна рекреація - катання на катамаранах, джампінг, скелелазіння, рибальство, що організовується в межах національних природних парків (НПП).

В Україні проекти створення НПП реалізуються 3 1980 р. Об'єктивними передумовами розвитку мережі НПП є потенційне та реальне зростання кількості туристів і необхідність упорядкування туристичних потоків. Першим в Україні був створений Карпатський НПП в масиві Чорногора в 1980 р. У 1983 р. створений Шацький НПП на вододілі річок Західний Буг і Прип'яті в районі Шацьких озер. Синевірський НПП створений у західній частині Вододільних Горган у верхів'ях річок Ріки та Тереблі, де на висоті 989 м розташоване озеро Синевір. У 1994-2000 рр. створені такі національні природні парки: Ужанський на Закарпатті, "Святі Гори" - у долині р. Сіверський Донець (Донецька обл.), Вижницький НПП (Чернівецька обл.), Азово-Сиваський НПП (Херсонська обл.), НПП "Подільські Товтри" у Хмельницькій обл. Одним із перших в Україні був створений Шацький НПП (Волинська обл.) площею 32,5 тис. га. Основна частина парку розташована на вододілі річок Західний Буг і Прип'ять в оточенні лісових масивів. Територією парку проходить дорога Львів - Брест, що свідчить про легку доступність парку для автотуристів.

У кожній області України, крім Дніпропетровської, Житомирської, Кіровоградської та Луганської, створено НПП. Вивчення й оцінювання природних можливостей НПП щодо надання туристичних послуг маломобільній групі населення й окреслення низки перспективних туристичних маршрутів, екскурсійних програм $€$ актуальними на сучасному етапі формування ринку адаптивного туризму.

В Україні налічується 41 національний природний парк загальною площею понад 1 тис. км² (1,8 \% території країни), які розташовані у 20 областях і АР Крим. Зараз тривають роботи зі створення НПП "Подесіння", який буде найбільшим в Україні (поки НПП "Подільські Товтри" залишається найбільшим за площею). У найближчій перспективі у Львівський обл. планується створити НПП "Чайковицький". Правові основи організації, охорони й ефективного використання національних природніх парків України як частини ії природнозаповідного фонду визначає Закон України "Про природно-заповідний фонд України" (рис. 4).

Для аналізу придатності НПП України й організації в їх межах перспективних туристично-екскурсійних маршрутів адаптивного спрямування були визначені й оцінені за відповідною методикою такі природні компоненти: 1) рослинний покрив (загальна характеристика); 2) рослинний покрив (дерева); 3) рослинний покрив (квіти); 4) орографрія; 5) гідрологічна характеристика; 6) орнітофрауна; 7) тваринний світ.

Результати кількісно-якісного оцінювання показників природних компонентів потенційної мережі туристично- 
екскурсійних маршрутів для потреб осіб із ознаками інвалідності в межах 25 НПП України вказує на можливості створення маршрутів різного спрямування для потреб туристів особливої категорії. Таким чином, згідно з результатами проведеного оцінювання, на територіях 21 НПП можуть бути створені або вже діють (згідно з державним реєстром) доступні туристично-екскурсійні маршрути. Аналіз потенційних чинників розвитку адаптивного туризму в НПП України є підґрунтям виявлення потенціалу цих територій щодо організації туристичноекскурсійних маршрутів для адаптивних туристів. Крім того, за областями й автономіями України було оцінено реальну та потенційну (очікувану) реакцію основних категорій осіб із ознаками інвалідності (6 груп), наприклад чуттєву реакцію (функціонування аналізаторів) на ті чи інші природні компоненти (умови) ландшафртів регіональних (міжрегіональних) НПП. Зіставлення, з одно- го боку, природних та інших можливостей (реалій) національних парків, їх ландшафтного наповнення, а з іншого - здатності адаптивних туристів і екскурсантів (групи дотику, запаху, слуху, зору, змішані) реагувати на ландшафтні компоненти, віддзеркалює табл. 2, яку умовно можна позиціонувати як взаємодію аналізаторів адаптивних туристів з територією НПП. Також широким спектром вирізняється можливість доступу й отримання послуг особам із різними видами фрізичних обмежень - 3 вадами опорно-рухового апарату, інвалідів-візочників, осіб із синдромом Дауна, хворих на ДЦП, сліпих, глухих, сліпоглухонімих тощо. Таким чином, національні природні парки можуть розглядатись як перспективні території для обґрунтування мережі екологічних стежок і розвитку туристично-екскурсійної діяльності, спрямованої на залучення осіб із ознаками інвалідності [11].

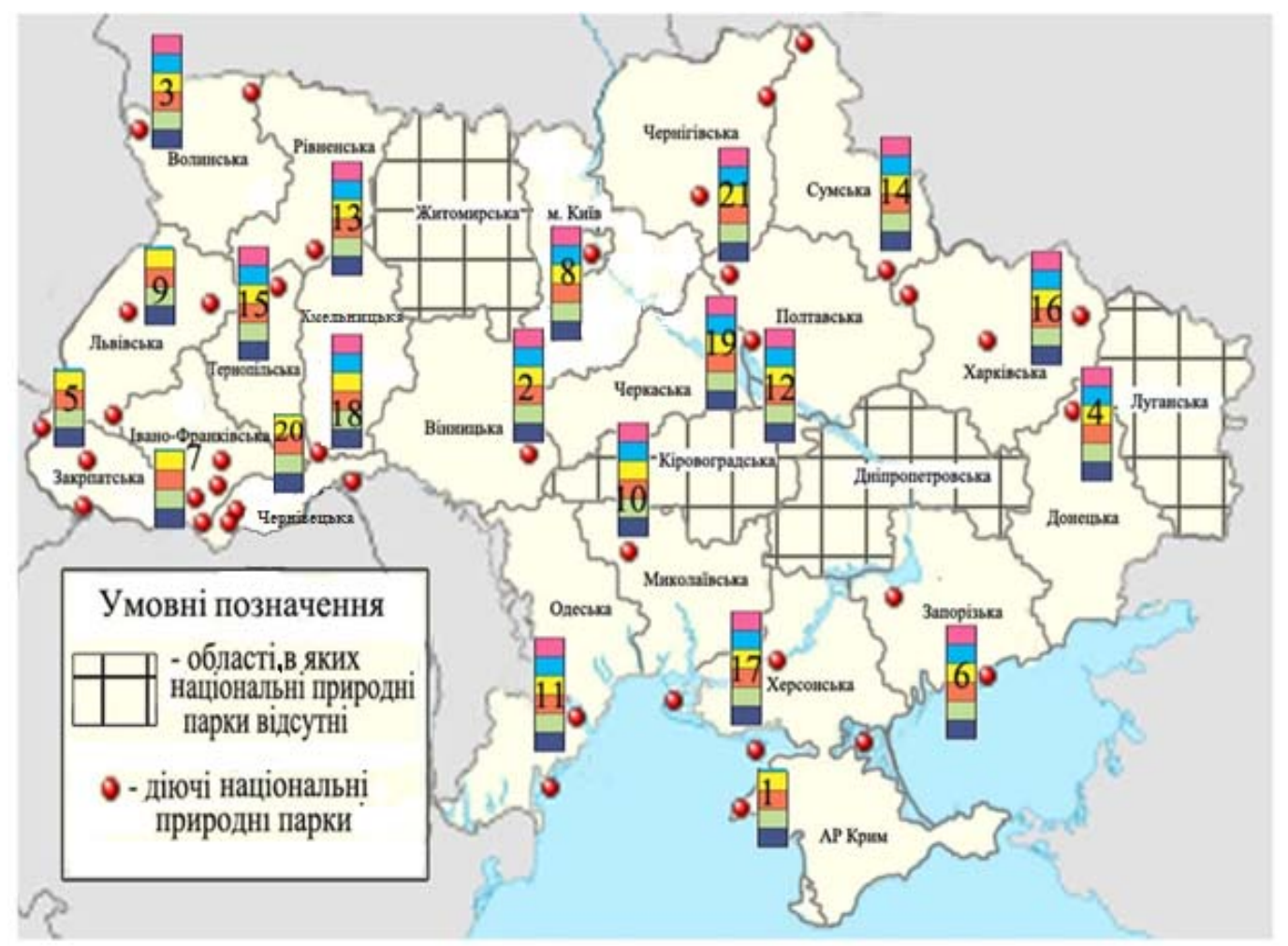

Національні природні парки (НПП) України:

1. НПП “Чарівна Гавань" (АР Крнм)
2. НПП "Кармалюкове Поділля'(Вінннщька обл.)

3. НПІІ "Прип'ять-Стохід” (Волннська обл.)

4. НІІІ "Святі Гори” (Донецька обл.)

5. НПП "Синевір” (Закарпатська обл.)

6. НПП "Приазовський” (Запорізька обл.)

7. НПП "Гуцульщина" (Івано-Франківська обл.)

8. НППП "Голосіӥвський" (Кнївська обл.)

9. НПП “Яворівський” (Львівська обл.)

10.НПП "Білобережжя Святослава"(Мнколаӥвська обл.)

11. НПП "Ніжньодністровський” (Одеська обл.)

12. НПП "Пирятинський” (Полтавська обл.)

13. НІІІ “Дермансько-Острозький” (Рівненська обл.)

14. НІІІ “Гетманський” (Сумська обл.)

15. НПІП “Дністровський каньон”(Тернопільська обл.)
16. НПП “Дворічанський” (Харківська обл.)

17. НПП “Олешківські піски'(Херсонська обл.)

18. НПП "Подільські Товтри” (Хмельннцька обл., Тернопільська обл.)

19. НПГП "Нижньосульський"(Черкаська обл.)

20. НПП "Вижницький”(Чернівецька обл.)

21. НПІІ “Мезинський”(Чернігівська обл.)

Категорії інвалідності адаптивних туристів

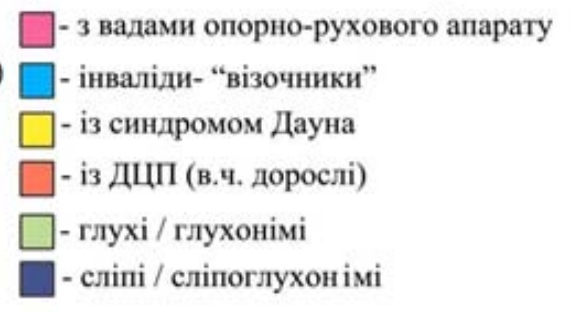




\section{Висновки:}

- навчальні базові дисципліни "Природокористування", "Економіка природокористування, "Рекреаційнотуристичне природокористування" розвивають конструктивно-географічні навички і спонукають студентську молодь до пошуку нестандартних рішень, мають важливе значення для формування екологічного мислення у студентів і підготовки кваліфікованих спеціалістів-географів;

- картографрічний метод і структурно-логічне моделювання $€$ важливою складовою інструментарію дослідження природних ресурсів і вивчення дисципліни "Природокористування";

- навчальна дисципліна "Природокористування" має гнучку будову, а її структура може трансорормуватися зі змінами суспільного замовлення на підготовку фрахівців природо-рекреаційного та природоохоронного профрілю;

- проведені дослідження та якісне оцінювання природних компонентів у межах НПП України може компенсувати неповний реєстр даних ресурсної бази адаптивного туризму і стати своєрідною "дорожньою картою" при реалізації різноманітних туристсько-адаптивних програм для маломобільної категорії населення.

Список використаних джерел:

1. Бейдик О. О. Унікальна Україна : географрія та ресурси туризму навч. посіб. / О. О. Бейдик, Н. О. Новосад. - К. : Альтерпрес, 2013.

2. Бейдик О. О. Рекреаційні ресурси України : навч. посіб. О. О. Бейдик. - К. : Альтерпрес, 2011.

3. Бейдик О. О. Діагностика адаптивного туризму / О. О. Бейдик, А. Л. Мельничук, А. В. Орещенко // Часопис картографії : зб. наук. праць. К. : КНУ ім. Тараса Шевченка, 2015. - Вип. 12. - С. 90-104

4. Бейдик О. О. Адаптивний туризм : передумови та перспективи розвитку, лідери Духу і Волі : навч. посіб. / О. О. Бейдик, О.І. Топалова. - Херсон : ОЛДІ-ПЛЮС, 2017.

5. Минц А. А. Экономическая оценка естественных ресурсов / А. А. Минц. - М. : Мысль, 1972.

6. Панченко Т. Ф. Туристичне середовище: архітектура, природа, інфраструктура / Т. Ф. Панченко. - К. : Логос, 2009.

7. Реймерс Н.Ф. Природопользование : словарь-справочник / Н. Ф. Реймерс. - М. : Мысль, 1990
8. Руденко В. П. Географрія природно-ресурсного потенціалу України / В. П. Руденко. - К. : Академія, 1999.

9. Руденко Л. Г. Стан виконання в Україні положень "Порядку денного на XXI століття" (2002-2012 рр.); за ред. Л. Г. Руденко. - К. : Академперіодика, 2014

10. Топалова О.І. Суспільно-географічні передумови та перспективи розвитку адаптивного туризму в Україні : автореф. дис. ... канд геогр. наук; спец. : 11.00.02 - "Економічна та соціальна географрія" / Олеся Іллівна Топалова. - К., 2016.

11. Шумский В. М. Этноландшафтная адаптация - путь к рациональному природопользованию / В.М.Шумский, О.И.Топалова // Культура народов Причерноморья. - 2010. - № 177. - С. 160-165.

12. Яковенко И. М. Рекреационное природопользование : методология и методика исследований : монография / И. М. Яковенко. - Симферополь : Таврия, 2003.

References:

1. Beydik O. O., Novosad N. O. Unikalna Ukraina : geografia ta resursy tyrizma / O. O. Baydik, N. O. Novosad // Navch. posib. - K.: Alterpres, 2013. $-572 \mathrm{~s}$

2. Beydik O. O. Rekreaziyni resursy Ukrainy / O. O. Baydik // Navch. posib. - K.: Alterpres, 2011. - $462 \mathrm{~s}$.

3. Beydik O. O., Melnichuk A. L., Oreshchenko, A.V., Diagnostica adaptivnogo turizmu // Chasopys kartografiy: Sb. naukovych statey. - K KNU. Taras Shevchenko, 2015. - Vol. 12. P. 90-104.

4. Beydik O. O. Topalova O. I. Adaptivniy turizm : peredumovy ta perspektyvy rozvytku : navch.posib - Kherson: OLDI-PLUS 2017. - 402 s.

5. Minz A. A. Ekonomicheskaja ozenka estestvennyx resursov / A. A. Minz. - M.: Mysl, 1972. - 302 s.

Panchenko T. F. Turystychne seredovyshe: architectura, pryroda, infrastructure.- K.: Logos, 2009.-176 s

6. Reimers, N. F. Prirodopolzovanie: slovar-spravochnik. - M.: Mysl, 1990. $-637 \mathrm{~s}$

7. Rudenko V. P. Geographia prirodno-resursnogo potenzialu Ukrainy / V. P. Rudenko. - K. : Academia, 1999. - $568 \mathrm{~s}$

8. Rudenko L. G. Stan vykonanja v Ukraine pologen "Porjadku dennogo na XXI stolittja" (2002-2012); za red. Rudenko L. G. - K. : Akademperiodika, 2014. -359 s.

9. Topalova O. I. Suspilno-geografichni peredumovy ta perspektyvy rozvytku adaptivnogo turizma $v$ Ukraini : avtoref. dis... kand. geogr. nauk; spez. : 10.00 .02 - ekonomichna ta sozialna geographia / O. I. Topalova K., 2016. $-175 \mathrm{~s}$

11. Shumskiy V. M. Etnolandshaftnaja adaptazija - put k razionalnomu prirodopolzovaniju / V. M. Shumskiy, O. I. Topalova // Cultura narodov Prichernomorija. - 2010. - №177. - S. 160-165.

12. Yakovenko I. M. Recreazionnoe prirodopolzovanie : metologija texnologija issledovanija [Text] : monografija / I. M. Yakovenko. - Simferopol : Tavria, 2003. $-331 \mathrm{~s}$

Надійшла до редколегї̈ 12.12.17

А. Бейдык, д-р геогр. наук, проф.

Киевский национальный университет имени Тараса Шевченко, Киев, Украина,

О. Топалова, канд. геогр. наук

Мелитопольский государственный университет имени Богдана Хмельницкого, Мелитополь, Украина

\section{ТЕОРЕТИКО-ПРАКТИЧЕСКИЕ АСПЕКТЫ РЕКРЕАЦИОННО-ТУРИСТИЧЕСКОГО ПРИРОДОПОЛЬЗОВАНИЯ}

Рассмотрено природопользование как одна из прикладных научных отраслей, которая базируется на природонаучных знаниях и комплексе фундаментальных социально-экономических дисциплин, с одной стороны, а с другой - как разветвленная и мощная практика и общественный опыт использования природных условий природных ресурсов. Раскрыты основные этапы наполнения и структура программы по природопользованию, которая составлена в соответствии с образовательно-профессиональной программой подготовки специалистов образовательно-квалификационного уровня "магистр" по направлению подготовки "Сфера обслуживания" и специальности "Туризм". Приведен ряд структурно-логических моделей по выбранной тематике. Проведенные исследования и качественная оценка природных компонентов в пределах НПП Украины могут компенсировать неполный реестр данных ресурсной базы адаптивного туризма и стать своеобразной "дорожной картой" при реализации разнообразных туристско-адаптивных программ для маломобильной категории населения.

Ключевые слова: природопользование, структурно-логическое моделирование, адаптивный туризм.

A. Beydik, Doctor of Science in Geography, Professor

Taras Shevchenko National University of Kyiv, Kyiv, Ukraine,

O. Topalova, PhD Geography, Senior lecturer

Bohdan Khmelnitsky State Pedagogical University of Melitopol, Melitopol, Ukraine

\section{THEORETICAL AND PRACTICAL ASPECTS}

OF RECREATION AND TOURISM ENVIRONMENTAL MANAGEMENT

Considered nature on the one hand as one of the applied scientific industries, is based on natural science knowledge and fundamental socioeconomic disciplines, and on the other, how extensive and powerful the practice and public experience in the use of natural conditions of natural resources. Describes the main stages the content and structure of the programme on environmental management, which is composed in accordance with the educational-professional programs of preparation of specialists of educational-qualifying level "master" in speciality "service industry", speciality "Tourism". Given the number of structurally-logic models of selected subjects. Conducted research and performed the qualitative assessment of natural components within the NPP of Ukraine can compensate for incomplete register data adaptive resource base of tourism and serve as a sort of "roadmap" in the implementation of various tourist and adaptive programs for the disabled population.

Keywords: environmental management, structural-logical modelling, adaptive tourism. 